\title{
HOSPITALIZATION OF TUBERCULOSIS PATIENTS
}

\author{
Vincent E. De Felice* and Dr. Ralph E. Dwork
}

Whereas a great majority of persons afflicted with tuberculosis have willingly entered a hospital for care and treatment of this disease, public health administrators have been faced with the growing problem of isolating individuals with tuberculosis in a communicable stage who have refused to enter a hospital or once they have entered a hospital have absented themselves from the hospital against the advice of the medical superintendent. Records reveal that individuals have absented themselves from hospitals against medical advice as many as eight times. For reasons immediately stated, these individuals have come to be known as recalcitrant patients. Many of these persons are alcoholics; some are psychotics; and some are just maladjusted enough to ignore their own best interests and those of the community.

In past years, due to the limited number of hospital beds, efforts were concentrated on hospitalizing those persons who were willing and eager to accept care and treatment. As better and earlier case finding methods were being developed, and efficacious drugs were being received and more aggressive surgery became available, hospital beds became more available. Fewer people are dying of tuberculosis year by year. The decrease in tuberculosis cases in the community has, however, not kept pace.

One reason for this continuation has been the inability to control tuberculosis recalcitrants as they made their way through a community from broadcasting tubercle bacilli. Here was a method by which the disease was being perpetuated. Public health administrators had the knowledge to control the spread of this disease as it pertained to the recalcitrant patients, but had no legal mechanism by which to do it.

This problem is not peculiar to Ohio, but rather is one that is confronting public health administrators in all segments of our nation. The states of Florida, California, Kentucky, Michigan, Georgia and Washington have enacted legislation similar to the law passed by the 101 st General Assembly of Ohio aimed to control the spread of tuberculosis by the recalcitrant patient.

In Ohio, the board of health of a city or general health district, upon the recommendation of the health commissioner, has had the authority to order removed to a municipal, county, or district tuberculosis hospital, any person suffering from pulmonary tuberculosis, when in the opinion of the board such person is a menace to the public health and cannot receive suitable care and treatment at home. ${ }^{1}$ Whereas this authority has been exercised by boards of health, a program of this nature

* Member, Ohio Bar and Chief, Legal Division, Ohio Department of Health. * Director, Ohio Department of Health.

1 Ohio Revised Code, Section 339.40. 
was not effective if the hospitalized individual absented himself from the hospital against medical advice. The Ohio Sanitary Code promulgated by the Public Health Council contains provision for the isolation of persons having tuberculosis and further provides that the patient shall remain in isolation as long as tubercle bacilli are being discharged by the patient. ${ }^{2}$ The Attorney General of Ohio has ruled that any person suffering from pulmonary tuberculosis in such an active stage that he is discharging tubercle bacilli, who neglects or refuses to isolate himself as required by the Ohio Sanitary Code, can be prosecuted for said violation by a local authority, and if found guilty, penalized. He pointed out, that if imprisonment is a part of the penalty, the infected person should be imprisoned in such a place and under circumstances as would prevent the direct or indirect conveyance of the infectious agents to susceptible persons. ${ }^{3}$ Due to the lack of proper isolation facilities, many areas have not been in a position to enforce this type of program.

Recognizing the ineffectiveness of Section 339.40 of the Ohio Revised Code and recognizing the non-existence of facilities permitting satisfactory enforcement of the Ohio Sanitary Code, the 101st General Assembly enacted Amended House Bill 127, which became effective August 5, 1955. The law is intended to be protective rather than vindictive, preventive rather than punitive.

The recent enactment authorized the Ohio Department of Health to construct, buy, lease, or contract for such a facility as may be necessary to carry out the provisions of the law, and further authorized departments of state and the political subdivisions of the state to contract with the department of health for such facilities. ${ }^{4}$ A facility for the purposes of the law means structures and equipment kept, used, maintained, or contracted for by the department of health for the purpose of housing persons with communicable tuberculosis who have been ordered removed pursuant to Section 339.52 of the Ohio Revised Code. ${ }^{5}$

The board of health of a city or a general health district, upon the recommendation of the health commissioner of the city or general health district, may apply to the probate court of the county in which the person resides or may be found, for an order to remove to a state tuberculosis facility, any person suffering from tuberculosis in a communicable stage who has refused to enter, or absents himself from any tuberculosis hospital against the medical advice of the medical superintendent, when in the opinion of the board of health such person is a menace to public health. ${ }^{6}$ Such application shall also state the names of witnesses by which the facts alleged therein may be proved, at least one of whom shall be a doctor of 
medicine. ${ }^{7}$ Evidence of tuberculosis in a communicable stage shall be based on one or both of two methods-chest X-ray findings interpreted as active tuberculosis by competent medical authority; and/or a laboratory report of sputum or other body fluid, secretion or excretion found to contain tubercle bacilli. ${ }^{8}$

A copy of the application, together with summons stating time and place of hearing shall be served upon the person three days prior to the time of hearing. The hearing shall be held in the probate court; however, for good cause shown, the court may in the order setting the time for the hearing direct the hearing to be held in such other place in the county as candidates may require. ${ }^{9}$

If, upon hearing, the probate court shall find the essential allegations of the application true, the said court shall enter a commitment order committing the person to a facility. If the court shall not so find, the application is dismissed and the person discharged. ${ }^{10}$ No person committed by virtue of this recently enacted legislation shall be required to submit to medical or surgical treatment in the facility to which he is committed without his written consent, or, if incompetent, without the written consent of his next of kin, or, if a minor, without the written consent of his legal or appointed guardian. ${ }^{11}$

Anytime after ninety days any patient committed to a facility by virtue of law may apply to the probate court of the county in which commitment order was entered to order his release for the reason that he is no longer suffering from tuberculosis in a communicable stage, and he, therefore, is no longer a menace to public health. If the court determines upon the hearing that the person committed is no longer a menace to public health by reason of his tuberculosis condition, the probate court shall enter an order releasing the person from his commitment and directing his discharge; if the probate court shall not so determine, it shall enter an order dismissing the application for release and remand the patient to the facility to which he was committed. ${ }^{12}$ The legislature enacted an additional provision relative to the discharge of a patient. When the director of health determines that the person committed is no longer a menace to public health by reason of his tuberculous condition, and so certifies to the probate court, the court shall enter an order releasing the person from his commitment and directing his discharge. ${ }^{13}$

In the event that a person committed to a facility is in need of services not available at the facility, but available elsewhere, and when it is in the best interest of the person, the director of health may authorize

\footnotetext{
7 Ohio Revised Code, Section 339.53.

8 Ohio Revised Code, Section 339.51.

9 Ohio Revised Code, Section 339.54.

10 Ohio Revised Code, Section 339.55.

11 Ohio Revised Code, Section 339.56.

12 Ohio Revised Code, Section 339.58.

13 Ohio Revised Code, Section 339.59.
} 
the temporary transfer of the patient from the facility to which he was committed to another state, county, district, or municipal tuberculosis hospital, or to another hospital approved by the department of health. Upon the conclusion of any diagnosis, care, and treatment, the person shall be returned to the facility to which he was originally committed. ${ }^{14}$

The expenses of removal of any person to a facility and of the care, treatment, and maintenance therein shall be borne by the county from which such person was committed. These expenses shall be paid from the general fund appropriations of the county or from funds derived from special levies. The county shall receive a subsidy from the state of one dollar and twenty-five cents per patient per day. ${ }^{15}$

The preceding statements constitute the basic provisions of the law, commonly referred to as the Recalcitrant Tuberculosis Law, enacted to protect society and based upon the legal principle that liberty implies absence from arbitrary restraint, not immunity from reasonable regulations imposed in the interest of society.

14 Ohio Revised Code, Section 339.60.

15 Ohio Revised Code, Section 339.63. 